\title{
JAMES ALFRED FORD, 1911-1968
}

\section{GORDON R. WILLEY}

$\mathrm{J}^{\mathrm{A}}$ AMES ALFRED FORD was born in Water Valley, Mississippi, on February 12, 1911. His father, also James Alfred Ford, and his mother, Janie David (Johnson) Ford, were both native Mississippians and of pioneer Scots-Irish stock. The senior Ford died when James was only three years of age; he was an employee of the IllinoisCentral Railroad and was killed in a train accident. Thereafter, James and a younger brother were raised by their mother, an intelligent and forceful woman who had been a schoolteacher and who returned to this profession after her husband's death. The Ford family resided in Water Valley until 1919 when they moved to Clinton, Mississippi. James (or Jim, as he was later to be known to friends and colleagues) attended the public High School in Clinton, graduating in 1927.

The source of his very early interest in archaeology remains somewhat obscure although it is probably significant that Jim had an uncle in Clinton who taught classics in the local Mississippi College and who may have turned him in this direction. In any event, in 1927, immediately after graduation from high school, Jim and a friend, Moreau B. Chambers, obtained jobs with the Mississippi Department of Archives and History in the state capitol at Jackson. The then director of this department was the late Dunbar Rowland, a southern historian of the old school, who put the boys to work digging for and collecting "Indian relics" from the numerous mounds of the state. Ford and Chambers spent three summers at this task of officially sponsored "pothunting," traveling from site to site by team and wagon. At first, they had no instruction or indoctrination, yet Jim's innate sense of order and system led him to devise rough attempts at field control in their excavations and to keep a set of notes. He has told me how they would establish bench marks on large trees near the mounds in which they were working and then measure the horizontal and vertical positions of their various finds with reference to these bench marks.

It was during this work with the Mississippi Department of Archives and History that Jim was to meet two people who were to feature very importantly in his life. One was Henry B. Collins, a young Mississippian who had been recently employed by the Smithsonian Institu- tion as an archaeologist and who was to bring Jim definitely into the profession of archaeology, and the other was a young lady, Ethel Campbell, then secretary to Dunbar Rowland, who was to become Mrs. James Ford.

In 1930, Collins was preparing to set out to Alaska for what was to prove to be a highly significant archaeological expedition. He offered Jim the post of field assistant. After persuading his mother, who was hesitant to let a 19-year old embark on such a distant voyage, but who was finally won over to Jim's wishes with the aid of the classics' professor uncle, the young man was allowed to accompany Collins to the Arctic. There, Collins excavated a series of sites at Gambel, on St. Lawrence Island. This early work with one of America's best archaeologists had a profound effect on Jim's attitudes toward methodological orientation in the field. I can remember, in talking with Jim in the mid-1930's, how his explanation of archaeological seriation was based largely on the St. Lawrence Island experience. Further, the Arctic - one of the last great frontiers of the republic - held a deep and romantic fascination for Jim. He was able to return to Alaska, again, in the summer of 1931, and this time he stayed for 18 months, working at Point Barrow and elsewhere. The theme of the Arctic, as a land and an idea, as well as a place of Eskimoan prehistory, was to remain as a part of Jim's life.

Ford attended Mississippi College in Clinton in the late 1920's and early 1930's although this attendance was intermittent, owing to the Alaskan trips. He did not graduate here, for in 1933 he stopped his formal schooling to obtain a National Council Research grant of funds to conduct investigations of archaeological sites in Mississippi and Louisiana. The results of the field work which he carried out under this grant were to be combined eventually with those which he and Chambers had obtained earlier in connection with the Mississippi Department of Archives and History; and the whole was to be presented in his first major work, Analysis of Indian Village Site Collections from Louisiana and Mississippi, which was published in 1936. This monograph established the outlines of archaeological chronology for this important part of the southeastern United States. Most of his research activities, including several minor pub. 


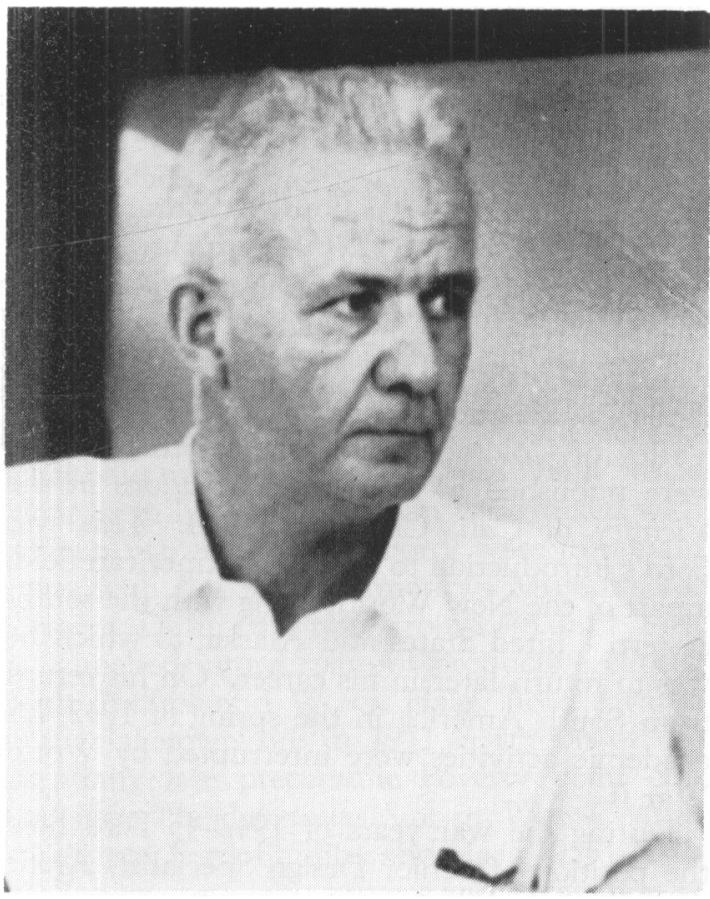

JAMES Alfred Ford

lications, between 1933 and 1936, led up to this important publication.

In 1933, following his NRC-sponsored surveys, Ford served as assistant to F. M. Setzler, at the excavations at Marksville, in east-central Louisiana. In this capacity he was able to see, at first hand, the resemblance between southern Marksville and northern Hopewell cultures and to help formulate the Hopewellian horizon or Burial Mound stage hypothesis which was to feature in his later writings. After his stint with Setzler, he spent several months with A. R. Kelly, at the Macon, Georgia, excavation, which, in 1933 and 1934, was one of the first and largest of the Federal Relief-supported archaeological field projects in the country. This experience greatly widened his knowledge of southeastern archaeological cultures. Later in 1934 he was employed by the Georgia State Park Service on what turned out to be an assignment in "applied archaeology." Ford was supposed to prove, by excavation, that an anomalous "tabby"-constructed ruin of the Georgia coast was, indeed, the romantic pile of an old Spanish mission. Instead, much to local dismay, he demonstrated with embarrassing convincingness, that the ruins in question were those of an early 19th-century sugar mill. Jim's "direct historical approach" in this instance gave evidence of the directness with which he was to handle other archaeological problems. He was never one to pull his punches or to suffer fools gladly.

In 1934 Jim became affiliated with the School of Geology at Louisiana State University, both as a student and as a Research Associate. His closest colleague in this institution was to be the cultural geographer, Fred Kniffen, who, like Henry Collins, was to play a role in Jim's intellectual development. Jim and Ethel Campbell were married in 1934, and in the fall of that year they settled in Baton Rouge, which was to be their home base until 1946. In 1936 Ford was awarded the B.A. degree at Louisiana State University, and he continued with graduate studies there. He also moved ahead with Lower Mis. sissippi Valley archaeological studies, and found time for another trip to the Arctic. The summer of 1937 was divided between the restoration of the "earth lodge" at the Macon, Georgia, site, a task for which he was hired as a special consultant by the National Park Service, and a field fellowship to Chaco Canyon, New Mexico. It was during the 1937 Macon job that I came to know Jim well. At the close of that summer, in a desire to go ahead with his graduate archaeological and anthropological training, and under the promptings of his friend and southeastern archaeological colleague, James B. Griffin, Ford decided to go to the University of Michigan.

Ford's stay at Michigan was relatively brief; he was there only for the academic year of 193738 , but the experience was extremely significant in his development. With Griffin, he gained a comprehensive knowledge of eastern United States archaeology beyond the SoutheastMississippi Valley regions with which he was already familiar. And from Leslie $A$. White he was to take a strong theoretical orientation in cultural evolution and "culturology." When Ford left Michigan he was a fully developed professional anthropologist and archaeologist, ready to go ahead full-steam on his career, although the actual Ph.D. degree was to come some years later.

His career was resumed immediately in the autumn of 1938, with the instigation of an LSU. WPA archaeological field program in Louisiana. Headquarters and laboratory for the project were in New Orleans, and excavations were begun at the Crooks Mound and Greenhouse sites, respectively in La Salle and Avoyelles parishes. The project was to continue until 1940. During its course, a great many of the then younger archaeologists working in eastern United 
States prehistory were to join Ford in it. R. S. Neitzel, W. T. Mulloy, A. R. King, Preston Holder, E. B. Doran, Walter Beecher, and Carlyle Smith were among the field supervisors; Andrew Albrecht worked as an ethnohistorian in connection with the project; and G. I. Quimby and myself were, at different times, in charge of the central laboratory. Among some of the publications resulting from these two years of investigations (see accompanying bibliography for full titles and references) are the Crooks Site (Ford and Willey 1940), The Tchefuncte Culture (Ford and Quimby 1945), and Greenhouse (Ford 1951). In general, the results accruing from this work confirmed but greatly refined the original Ford sequence of archaeological cultures in the Lower Mississippi Valley, and a significant addition was made to that sequence by the addition of the Tchefuncte culture to the bottom of it. Although much of the work was collaborative, the guiding and driving intelligence throughout was Ford's. Ever generous in sharing credit, he left no doubt as to where leadership lay, and he was a magnificent research leader.

This quality of leadership was also expressed beyond the bounds of his own "team." Recognizing the need for an interchange of information and ideas in the wake of the rapidly accumulating data from the burgeoning Federal Relief archaeological programs in the South, Ford was a prime mover in the organization of what was to be known - and what continues today - as the Southeastern Archaeological Conference. Together with Griffin, he planned and organized the first one which was held in Ann Arbor, Michigan, in the spring of 1938. Afterwards, he continued as the moving spirit in the subsequent meetings of the group.

In 1939-40, taking part time out from his duties as project director in Louisiana, Ford joined with Griffin and Philip Phillips, to run a systematic survey of collecting and test digging in the Mississippi Valley of eastern Arkansas and adjacent western Mississippi. Among the prime objectives in the new survey were the search for the origins of Middle Mississippi culture and a tracing out of the relationships of the Louisiana-south Mississippi culture sequence to other sequences to be established in the north. Partially successful in these objectives, this investigation also opened up a host of new problems. Today the monograph resulting from it (Archaeological Survey in the Lower Mississippi
Alluvial Valley, Phillips, Ford, and Griffin 1951) is the departure point for all future research in the area.

Ford entered Columbia University to complete his graduate work for the doctorate in anthropology in the fall of 1940 . At the close of the academic year in May of 1941 he then joined Wendell C. Bennett, of Yale University, to take part in a newly organized Institute of Andean Research program of archaeology in Latin America. He and Bennett worked in the Cauca Valley of Colombia, and some of their results were published by Ford as Excavations in the Vicinity of Cali, Colombia, 1944. This was Ford's introduction to the Latin American field, a part of the New World, along with the southeastern United States and Alaska, to which he was to return later in his career. On his return from South America in the spring of 1942, his academic activities were interrupted by World War II.

During the war years of 1942-45 Ford held the position of Senior Design Specialist, Arctic and Winter Warfare, in the Research and Development Branch, Office of the Quartermaster General, U.S. Army. He was engaged in designing equipment and clothing for Arctic conditions and in supervising field tests of such materials in Alaska and the Aleutians. With his knowledge of the north and of Eskimo life, his flair for practical skills of all kinds, his ranging, rugged physique, and his adventurousness, he was ideally suited to these tasks. He served well and uncomplainingly but secretly chafed to get back to archaeology.

With the end of the war, Ford returned to Columbia University, continued his preparations for the Ph.D. examinations, and passed those in early 1946. Immediately afterward he joined Duncan Strong, Wendell Bennett, my* self, and others in the Virú Valley venture in northern Peru. This was a concentrated attack on the prehistory, geography, and social anthropology of a single coastal valley. Ford's contribution to the overall program was the ceramic dating of over 300 archaeological sites (see Surface Survey of the Virú Valley, Peru, Ford and Willey 1949). In this study, which was connected with my own settlement pattern studies, we worked closely. Since then, I have often thought that my settlement sample might not have been so heavily weighted on the side of high rocky-crag fortifications if Jim had not been urging me on, in the exploratory spirit, to rise to meet these mountain-climbing challenges. 
Un-Spartan-like, I would have more readily tarried in the cities of the plain, if I had been left to my own devices.

Before setting off on the Virú expedition Ford had accepted a curatorial position at the American Museum of Natural History; so at the close of the Peruvian work he returned there. With an instinctive dislike of the big city, he settled far from it, in the pleasant community of Tarrytown, joining his friends and museum colleagues, Gordon Ekholm and the late Harry Tschopik, who also lived in that neighborhood. Jim and Ethel built a house there, the word "built" to be taken literally. Most of it Jim constructed with his own two hands. The Fords were to remain there, with Jim at the American Museum, for 18 years. During this time, from 1946 until 1964, he launched into a spate of productive efforts. With Phillips and W. G. Haag, he excavated at the Jaketown site in 1951, a station of the essentially late preceramic Poverty Point culture (see The Jaketown Site in West-Central Mississippi, Ford, Phillips, and Haag 1955). This was followed up with surveys and excavation at the huge Poverty Point earthworks in Louisiana, a program carried out in collaboration with C. H. Webb (Poverty Point, Ford and Webb 1956) in the middle of the 1950's. In 1958 he excavated the old Quapaw town located on the Menard place on the Arkansas River (see Menard Site, Ford 1961). This was done in cooperation with the National Park Service. In 1960-61 Ford dug some Hopewellian burial mounds near Helena, Arkansas (see Hopewell Culture Burial Mounds Near Helena, Arkansas, Ford 1963).

The swiftness with which Ford published sets an admirable standard for his colleagues. All of these above works were brought out in the American Museum of Natural History series. So also was his Eskimo Prehistory in the Vicinity of Point Barrow, Alaska (Ford 1959). This exception to speediness was based upon notes going back to Ford's early work of the 1930's in the Arctic. He was able to draw these materials together and, with the aid of a final northern field trip in the summer of 1953, to discharge his obligations with regard to this 20 -year-old research. Meanwhile, in the decade of the 1950's and the early 1960's, these numerous activities were supplemented by still others. He investigated early-man sites in the Texas Panhandle, served as a consultant with the Louisiana State Park Service in connection with their program for Marksville, took time for a 1958-59 season's survey on the far north coast of Peru, began an NSF-supported study of alluvial valley changes and the relation of these to early aboriginal occupancy in the Mississippi Valley in 1961-62, and helped organize and participate in a summer teaching symposium in archaeological field methods which was held at the Universidad del Atlantico in Barranquilla, Colombia, in 1961. In this last venture he was joined by his friends, Betty J. Meggers and Clifford Evans of the Smithsonian Institution. He was also President of the Society for American Archaeology in 1963-64.

Before leaving the American Museum, Jim's last major field project was an archaeological survey and excavation program on the Veracruz coast of Mexico. In this, he was following out an old idea and wish: to examine this region for clues of Mesoamerican-to-southeastern United States diffusions or migrations. In Veracruz, he worked in close cooperation with a young Mexican colleague, Alfonso Medellín Zenil. In the course of this project he left the American Museum and took up a position at Florida State Museum in Gainesville; the Mesoamerican work proceeded, however, until 1966.

As an outgrowth of these Veracruz surveys, Ford began to review not only the possibilities of Mesoamerican-eastern United States connections but the possible interrelationships of a number of early ceramic complexes elsewhere in the Americas. It was his concept that an "American Formative" base for all later potterymaking-agricultural societies could be traced to certain early Nuclear American beginnings. The Meggers-Evans-Estrada Valdivia pottery of coastal Ecuador, the origins of which these authors see as lying in the Jomon ceramic tradition of Japan, was brought into Ford's diffusionist reconstructions. Ford published a preliminary paper ("Early Formative Cultures in Georgia and Florida," 1966) on some of these ideas, opting, especially, for Ecuadorian-Caribbean stimuli as the source of some of the early incised and punctated fiber-tempered pottery of the southeastern United States. As in the old Southeastern archaeological days of 30 years before, Jim called for a conference of specialists to argue out and plot these problems of "American Formative" diffusions. A number of his most distinguished American colleagues joined him in this, in the autumn of 1966, in Gainesville. The meeting was most successful, and Ford moved on with ever greater enthusiasm for what was to be his 
last great synthesis of American archaeological data.

For in the spring of 1967 James Ford was stricken with what was to be a fatal illness. Knowing of his own condition, he, nevertheless, pushed on, growing steadily weaker but refusing to give up. It was a fight against time, but he won it. A few days before his death, which occurred in Gainesville, Florida, on February 25, 1968, he completed the manuscript of his last major work: A Comparison of Formative Cultures in the Americas: Diffusion or the Psychic Unity of Man? This was the final act of this extraordinarily gifted and productive man.

It is a not very original but, nevertheless, poignant commentary on human relationships that compeers and contemporaries, while being aware of the unusual abilities of one of their number, seemed constrained to give voice to a recognition of this while he is alive. Some obvious reasons for this are the rivalries, arguments, and pursuits of the day; but, perhaps even more important is that we are inclined to take our fellow men and colleagues for granted. An individual's notable capacity for hard work or his fantastic facility for cutting through mounds of data to the heart of the matter are, if we know him well, often accepted as a commonplace. Only when he has gone does our recognition of such things surface. All of this, I think, pertains to Jim Ford. I do not mean to imply that he was not well regarded by his colleagues; he was both beloved and respected. At the same time, I think, it will be retrospectively, in the decades to come, that we will appreciate the truly great value of his contribution to American archaeology.

In the early 1930's, archaeology in the eastern United States was ripe for a change. A younger generation of scholars had moved from the kind of "Mound-Builder" antiquarianism which had prevailed earlier to a more systematic-descriptive point of view. New excavation and recording techniques had been introduced, especially by the University of Chicago group. The Federal Relief programs in the southern states were making possible a whole new series of excavations on a scale that had never been known in the area before, and a host of young archaeological students, eager for the opportunities, were being called upon to man these operations. All of the elements for intellectual excitement were there; only the excitement was missing. The reason for this, I believe, was the lack of a larger sense of historical problem and purpose. The East had not enjoyed the full benefits of the "stratigraphic revolution" which had begun to transform Southwestern archaeology almost 20 years earlier with the publication of Nelson's and Kidder's work. In a sense, Eastern archaeology had not yet become prehistory; it lacked the chronological dimension, what Duncan Strong once called "the nerve of history." It was in this setting that James Ford made his appearance and his greatest contribution.

The power of Ford's personality was overwhelming. One remembers the spare, 6-ft. 4-in., Lincolnesque frame, the wide, slightly hunched shoulders, the deep-set, intense eyes. Clearly, there was a quality of the messianic about him - as there may be in all innovators. One tended to be either drawn up and swept along in his enthusiasm or somewhat hostile toward and suspicious of it, and contemporaries in the early Southeastern Archaeological Conference meetings reacted both ways. In either case, the effects were all to the good. The arguments were hot and electrifying. No one left who did not know more Southeastern archaeology than he had before he came and who did not see his substantive knowledge in better overall historical perspective.

Ford knew that the fundamentals of artifact typology would be the building stones of any Southeastern spatial-temporal framework of cultural complexes. His own extensive and intensive earlier work with the Louisiana and Mississippi pottery collections stood him in good stead as the chief advocate of a systematic ceramic typology and nomenclature. In his drive for such a system, and for the full participation of his colleagues in it, he never took his eye off the ball. Objections such as, "why all the emphasis on pottery, why not other aspects of culture?," failed to deflect him. His answer would be, "go ahead, fine, but let's not forget that the abundance and wide presence of potsherds offers us a means of cross-regional comparisons that will link the entire East." One of his favorite conference devices was to line his colleagues up around the blackboard, each regional specialist to his own column, and then have a community "arguing out" of which pottery complexes matched with or equated with which others in the neighboring columns. Much later in 1966, with the theatre of operations now extended from the southeastern United States to Peru, he was still doing this. The method is simple, and has its limitations, but it is a highly effective way to engage all of the participants of 
a conference in the construction of a space-time framework of the basic facts.

Ford also saw that reliable refuse stratigraphy was relatively hard to come by in Eastern archaeology. As had been pointed out by other workers, many sites were thin, single-component occupations. To overcome this limitation, and also to move as rapidly as possible toward a series of regional culture sequences, he advocated surface survey and seriation of pottery surface collections on a principle of similiary seriation. This seriation was geared to percentage computations of individual types per unit collection, and type percentages were so arranged graphically as to form the familiar "battleship"shaped figures depicting stylistic inception, popularity, decline, and extinction. The cultural theory on which this treatment of the data was based was that of a uniform, gradualistic change which, of course, the graphs seemed to attest. Critics have pointed out - and I think rightly that stylistic change does not always proceed in this smoothly gradual fashion; nevertheless, the method gave a generally sound means for the initial chronological structuring of a region from survey data.

But Ford's greatest interests lay beyond typological and methodological formulations. He was aware of the flow of history, and he wanted to demonstrate this over as wide and deep a range, geographically and chronologically, as possible. As does any such pioneer synthesizer, he moved "ahead" of the data. The remarkable article, "An Interpretation of the Prehistory of the Eastern United States," in which I collaborated with him and which was published in 1941 , is an example. I use the word "remarkable" without embarrassment even though I was a coauthor. The vision and the bold conceptions were Ford's; my own role was a very junior one of formal organization and the injection of occasional cautionary and qualifying statements. Ford felt that the impact of the ideas which the article carried were of greater importance to Eastern archaeology at that time than the negative circumstance of speculation outrunning factual proof. The difference in our attitudes can be measured by Ford's original title for the piece, "A Key to the Prehistory, etc." I substituted the more timid word, "Interpretation," in a last look at the galley-proof, without Jim's knowledge, a deed which he rightly considered pusillanimous on my part. The essay, though in many ways crude and naive, was the first broad perspective of the archaeology of the East which imparted a sense of history; some of it has since been corrected, but much of it stands.

In Latin America, Jim had the role of a teacher or archaeological "missionary": first, by example, as in the Virú Valley work, where he introduced potsherd studies into a Peruvian archaeological setting that had, up to that time, been largely dominated by the study of grave-lot collections, and second, as a seminar instructor when, together with Meggers and Evans, he propounded his stratigraphic and seriational techniques to young Latin American archaeologists at the Barranquilla symposium. His influence has been, and will continue to be, felt in South and Middle American archaeology. It should be noted in this connection that Jim Ford was an excellent teacher, in spite of his many denials that he wanted no part of the life of an academic lecturer. He was at his best working together with younger people, in a seminar, laboratory, or field situation. Finally, Ford's Latin American contribution and influence is also expressed in his very last work on the diffusion and spread of what he called the "American Formative cultures." The diffusionist hypotheses presented in his writings on this subject are currently the center of attention and debate - as much so, in fact, as were Ford's ideas almost 30 years ago. Present archaeological consensus is inclined to view the "American Formative" warily. In my own opinion, a good part of what he has advanced will one day be accepted.

As a theoretician, as has been indicated, Ford was a committed cultural evolutionist with a definitely deterministic turn of mind. To him, archaeology (and anthropology) was a science, and it was his expressed desire to make it ever more so in a quantitative and empirical way. The unimodal curves of his pottery-type lifehistory graphs were, in his view, expressions of the superorganic and could be understood only as such. People were only the "carriers" of culture, not the causative agents of it, and to attempt to look below the "culturological" level was, to Ford, reductionistic and futile. He defended this point of view frequently in print (e.g., "On the Concept of Types," 1954; "A Whimper from a Pink Granite Tower," 1964).

And yet I cannot help but feel that there was some inner conflict here in Ford's own mind between what he so ardently professed and what he thought, perhaps almost subconsciously. His interests and his outstanding contributions were so powerfully historical. To be sure, he thought of himself as quantifying the flow of culture 
history, of "measuring" it as it moved passionless through predetermined channels; but, curiously, he never went beyond simple percentage formulations to more complex statistics in this search for quantification, although there were available models for these procedures. Nor did he seem particularly interested in the mechanisms of cultural process or causality, other than to subsume them under the general formula that culture evolves from culture. My own belief is that Ford was more fascinated with the content and the qualitative aspects of culture and culture history than he would admit, even to himself.

For James Ford was a romantic as well as a scientist. I have often remembered his telling me that the only literary man he had ever admired was Mark Twain. This is significant in an understanding of Jim. The two men had much in common. Both were peculiarly American geniuses, and both were southern Americans. The tragic fate of the South had left both without an appropriate heritage. Thus, each, in his own time, stood somewhat apart from the successful and "progressive" North, being attracted by its technological and scientific proficiency but also oppressed by the meretricious materialism of this image of the "future." And because of this, each sought to escape to some purer vision of the American dream and man's destiny - to Huck Finn and his Odyssey of the wilderness or to archaeology and those ultimate truths of man's past. Like Twain, Ford was a romantic who scoffed bitterly at romanticism, proclaiming the practical. Like Twain, also, a courageous optimism and a dark pessimism warred in his nature. Out of these tensions came the singular creative drive of James Alfred Ford.

Acknowledgments. I am indebted to C. H. Webb of Shreveport, Louisiana, and to J. C. Dickinson, Jr., Director of the Florida State Museum at Gainesville, for aid in providing data on Ford's life. The former has also prepared an obituary statement of Ford (to be published in the Texas Archaeological and Paleontological Bulletin). Clifford Evans, Jr. and B. J. Meggers very kindly provided me with the photograph of Ford, one which they took at a recent archaeological conference. Evans and Meggers have also checked the bibliography which appears with this obituary and which has been prepared and annotated by Stephen Williams.

HARVARD UNIVERSITY

Cambridge, Massachusetts June, 1968

\section{A Bibliography of James Alfred Ford Compiled by Stephen Williams}

1932

Archeological Work in Alaska. Science, n.s., Vol, 75, No. 1935, p. 9. Lancaster.

Studying Eskimo Mounds in Alaska. El Palacio, Vol. 32, Nos. 10-11, pp. 155-6. Santa Fe.

Eskimo Burial Customs. El Palacio, Vol. 33, Nos. 21-22, pp. 198-9. Santa Fe.

\section{4}

Mound Builders Were Pit Dwellers. El Palacio, Vol. 36, Nos. 9-10, pp. 74-5. Santa Fe.

\section{5}

An Introduction to Louisiana Archeology. Louisiana Conservation Review, Vol. 4, No. 5, pp. 8-11. New Orleans.

Outline of Louisiana and Mississippi Pottery Horizons. Louisiana Conservation Review, Vol. 4, No. 6, pp. 33-8. New Orleans.

Ceramic Decoration Sequence at an OId Indian Village Site Near Sicily Island, Louisiana. Louisiana Department of Conservation, Anthropological Study, No. 1. Louisiana Geological Survey, New Orleans.

\section{6}

Analysis of Indian Village Site Collections from Louisiana and Mississippi. Louisiana Department of Conservation, Anthropological Study, No. 2. Louisiana Geological Survey, New Orleans.

\section{7}

An Archaeological Report on the Elizafield Ruins. In Georgia's Disputed Ruins, edited by E. Merton Coulter, pp. 190-225. University of North Carolina Press, Chapel Hill.

(with James B. Griffin) A Proposal for a Conference on Pottery Nomenclature for the Southeastern United States. Ann Arbor. 5 pp. (Mimeographed for circulation to members of the Southeastern Conference).

Review of "Ceramic Relationships of the Pre-Caddo Pottery from the Crenshaw Site," by S. D. Dickinson. American Antiquity, Vol. 3, No. 2, pp. 195-6. Menasha.

\section{8}

(with James B. Griffin) Report of the Conference on Southeastern Pottery Typology. Proceedings of the First Southeastern Archaeological Conference. Ann Arbor. 14 pp. (Mimeographed)

A Chronological Method Applicable to the Southeast. American Antiquity, Vol. 3, No. 3, pp. 260-4. Menasha.

An Examination of Some Theories and Methods of Ceramic Analysis. MS, M.A. thesis, Department of Anthropology, University of Michigan, Ann Arbor. $91 \mathrm{pp}$.

\section{9}

Archaeological Exploration in Louisiana During 1938. Lonisiana Conservation Review, Vol. 7, No. 4, pp. 1517. New Orleans.

(with Gordon R. Willey) Lower Mississippi Valley Pottery Types: I. Southeastern Archaeological Conference, Newsletter, Vol. 1, No. 3, pp. 1-12. Lexington. 
(with Gordon R. Willey) Lower Mississippi Valley Pottery Types: II. Southeastern Archaeological Conference, Newsletter, Vol. 1, No. 4, pp. 1-8. Lexington.

\section{0}

(with Gordon R. Willey) Crooks Site, a Marksville Period Burial Mound in La Salle Parish, Louisiana. Louisiana Department of Conservation, Anthropological Study, No. 3. Louisiana Geological Survey, New Orleans.

Review of "Handbook of Northern Arizona Pottery Wares," by H. S. Colton and L. L. Hargrave. American Antiquity, Vol. 5, No. 3, pp. 263-6. Menasha.

\section{1}

(with Gordon R. Willey) An Interpretation of the Prehistory of the Eastern United States. American Anthropologist, Vol. 43, No. 3, pp. 325-63. Menasha.

\section{4}

Excavations in the Vicinity of Cali, Colombia. Yale University Publications in Anthropology, No. 31. Yale University Press, New Haven.

\section{5}

(with George I. Quimby, Jr.) The Tchefuncte Culture, an Early Occupation of the Lower Mississippi Valley. Memoirs of the Society for American Archaeology, No. 2. Menasha.

\section{8}

Review of "Indians Before Columbus," by P. Martin, G. Quimby, and D. Collier. The American Indian, Vol. 4, No. 3, pp. 54-5. American Association of Indian Affairs, New York.

\section{9}

(with Gordon R. Willey) Surface Survey of the Virú Valley, Peru. American Museum of Natural History, Anthropological Papers, Vol. 43, Pt. 1. New York.

Review of "Our Summer with the Eskimos," by Constance and Harmon Helmericks. Natural History, Vol. 58, No. 7, p. 335. New York.

\section{0}

Review of "Man in the Primitive World," by E. Adamson Hoebel. Natural History, Vol. 59, No. 2, pp. 55, 96. New York.

\section{1}

(with Philip Phillips and James B. Griffin) Archaeological Survey in the Lower Mississippi Alluvial Valley, 19401947. Harvard University Peabody Museum, Papers, Vol. 25. Cambridge.

Greenhouse: a Troyville-Coles Creek Period Site in Avoyelles Parish, Louisiana. American Museum of Natural History, Anthropological Papers, Vol. 44, Pt. 1. New York.

Review of "Excavations in Southeast Florida," by Gordon R. Willey, and "Excavations on Upper Matecumbe Key, Florida," by John M. Goggin and Frank H. Sommers, III. American Anthropologist, Vol. 53, No. 1, pp. 118-19. Menasha,

Review of "Fishing in Many Waters," by James Hornell. Natural History, Vol. 60, No. 1, p. 5. New York.
1952

Measurements of Some Prehistoric Design Developments in the Southeastern States. American Museum of Natural History, Anthropological Papers, Vol. 44, Pt. 3, pp. 313-84. New York.

Mound Builders of the Mississippi. Scientific American, Vol. 186, No. 3, pp. 22-7. New York.

Reply to "The Virú Valley Sequence: a Critical Review." American Antiquity, Vol. 17, No. 3, p. 250. Salt Lake City.

Mound Builders and Mounds. Encyclopedia Americana, Vol. 19, pp. 521-3. New York.

Review of "Archaeology of the Florida Gulf Coast," by Gordon R. Willey. American Journal of Archaeology, Vol. 56, No. 2, p. 239. Princeton.

Review of "Hudson's Bay Trader," by Lord Tweedsmuir. Natural History, Vol, 61, No. 4, p. 149. New York.

Archaeology: Western Hemisphere. Britannica Book of the Year, 1953, pp. 51-3. Encyclopedia Britannica, Chicago.

Review of "Hopewellian Communities in Illinois," edited by Thorne Deuel. American Antiquity, Vol. 19, No. 1, p. 97. Salt Lake City.

Review of "Archaeology of the Eastern United States," edited by James B. Griffin. American Antiquity, Vol. 19, No. 2, p. 172. Salt Lake City.

Review of "Culture Periods in Eastern United States Archaeology; Radiocarbon Dates for the Eastern United States," by James B. Griffin. American Antiquity, Vol. 19, No. 2, pp. 189-90. Salt Lake City.

Review of "Icebound Summer," by Sally Carrigher. Natural History, Vol. 62, No. 8, p. 340. New York.

\section{4}

Additional Notes on the Poverty Point Site in Northern Louisiana. American Antiquity, Vol. 19, No. 3, pp. 282-5. Salt Lake City.

Comment on A. C. Spaulding, "Statistical Techniques for the Discovery of Artifact Types." American Antiquity, Vol. 19, No. 4, pp. 390-1. Salt Lake City.

The History of a Peruvian Valley. Scientific American, Vol. 191, No. 2, pp, 28-34. New York.

On the Concept of Types: The Type Concept Revisited. American Anthropologist, Vol. 56, No. 1, pp. 42-57. Menasha.

Spaulding's review of Ford: I. American Anthropologist, Vol. 56, No. 1, pp. 109-12. Menasha.

\section{5}

(with Philip Phillips and James B. Griffin) Archaeological Field Work - the Survey. In Readings in Anthropology, by E. Adamson Hoebel and others, pp. 17-21. New York.

(with Philip Phillips and William G. Haag) The Jaketown Site in West-Central Mississippi. American Muse. um of Natural History, Anthropological Papers, Vol. 45, Pt. 1. New York.

Poverty Point Excavations. Science, n.s., Vol. 122, No. 3169, pp. 550-1. Lancaster.

The Puzzle of Poverty Point. Natural History, Vol. 64, No. 9, pp. 466-72. New York. 
Review of "Dangerous River," by R. M. Patterson. Natural History, Vol. 64, No. 3, p. 117. New York.

Review of "Fifty Years in Alaska," by Carl J. Lomen. Natural History, Vol. 64, No. 3, p. 119. New York.

\section{6}

(with Junius B. Bird) A New Earth-shaking Machine. American Antiquity, Vol. 21, No. 4, pp. 339-401. Salt Lake City.

(with Clarence H. Webb) Poverty Point, a Late Archaic Site in Louisiana. American Museum of Natural History, Anthropological Papers, Vol. 46, Pt. 1. New York.

Review of "Birthplace of the Winds," by Ted Bank, II. Natural History, Vol. 65, No. 5, p. 228, 230. New York.

Review of "Excavations at Kolomoki: Season I, 1948; Season II, 1950; Season III and IV, Mound D," by William H. Sears. American Anthropologist, Vol. 58, No. 1, pp. 198-200. Menasha.

Review of "Investigaciones arqueologicas en la Sabana de Bogota, Colombia (Cultura Chibcha)," by E. W. Haury and J. C. Cubillos. American Antiquity, Vol. 22, No. 1, pp. 91-2. Salt Lake City.

Review of "Land of the Long Day," by Doug Wilkinson. Natural History, Vol. 65, No. 6, p. 287. New York.

Review of "Recent Discoveries Suggesting an Early Woodland Burial Cult in the Northeast," by William A. Ritchie. American Antiquity, Vol. 21, No. 3, pp. 330-1. Salt Lake City.

Review of "World Book of Great Inventions," Natural History, Vol. 65, No. 5, p. 278. New York.

\section{7}

Early Man in America. Natural History, Vol. 66, No. 8, pp. 406-07. New York.

1959

Eskimo Prehistory in the Vicinity of Point Barrow, Alaska. American Museum of Natural History, Anthropological Papers, Vol. 47, Pt. 1. New York.

(dated 1957) Metodo cuantitativo para determinar la cronologia arqueológica. Divulgaciones Etnologicas, Vol. 6, pp. 9-43. Universidad del Atlántico, Instituto de Investigación Etnológica, Barranquilla.

\section{0}

(with James B. Griffin) A Proposal for a Conference on Pottery Nomenclature for the Southeastern United States. Southeastern Archaeological Conference, Newsletter, Vol. 7, No. 1, pp. 5-9. Cambridge.

(with James B. Griffin) Report of the Conference on Southeastern Pottery Typology. Southeastern Archaeological Conference, Newsletter, Vol. 7, No. 1, pp. 1022. Cambridge.

Review of "Two Weeden Island Period Burial Mounds, Florida," by William H. Sears. American Antiquity, Vol. 26, No. 1, p. 132. Salt Lake City.

\section{1}

Excavation of the Hopewell Culture Burial Mounds at Helena, Arkansas. Arkansas Archeological Society, Newsletter, Vol. 2, No. 1, pp. 13-14. Fayetteville.
An Archaeological Survey in the Alluvial Valley of the Mississippi River. Arkansas Archeological Society, Newsletter, Vol. 2, No. 5, pp. 12-14. Fayetteville.

In Favor of Simple Typology. American Antiquity, Vol. 27, No. 1, p. 113-14. Salt Lake City.

Menard Site: the Quapaw Village of Osotouy on the Arkansas River. American Museum of Natural History, Anthropological Papers, Vol. 48, Pt. 2. New York.

\section{2}

A Quantitative Method for Deriving Cultural Chronology. Technical Manual, I. Pan American Union, Washington.

Metodo cuantitativo para establecer cronologias, culturales. Manuales Tecnicos, III. Unión Panamericana, Washington.

Kolichestvennyi metod ustanovleniia arkheologicheskoi khronogolii. Sovetskaia Etnografiia, No. 1, pp. 32-43. Moscow.

Review of "The Belcher Mound: A Stratified Caddoan Site in Caddo Parish, Louisiana," by Clarence H. Webb. American Anthropologist, Vol. 64, No. 1, pp. 202-03. Menasha.

\section{3}

Hopewell Culture Burial Mounds Near Helena, Arkansas. American Museum of Natural History, Anthropological Papers, Vol. 50, Pt. 1. New York.

\section{4}

A Whimper From a Pink Granite Tower. American Anthropoolgist, Vol. 66, No. 2, pp. 399-401. Menasha.

\section{5}

Review of "Prehistoric Man in the New World," edited by Jesse D. Jennings and Edward Norbeck. American Anthropologist, Vol. 67, No. 1, pp. 157-9. Menasha.

Review of "Issaquena: An Archaeological Phase in the Yazoo Basin of the Lower Mississippi Valley," by Robert E. Greengo. American Anthropologist, Vol. 67, No. 6, Pt. 1, pp. 1589-90. Menasha.

\section{6}

Early Formative Cultures in Georgia and Florida. American Antiquity, Vol. 31, No. 6, pp. 781-99. Salt Lake City.

\section{7}

Review of "Manual de arqueologia americana," by Jose Alcina Franch. American Antiquity, Vol. 32, No. 2, pp. 245-6. Salt Lake City.

Review of "Early Formative Period of Coastal Ecuador The Valdivia and Machalilla Phases," by Betty J. Meggers, Clifford Evans, and Emilio Estrada. American Antiquity, Vol. 32, No. 2, pp. 258-9. Salt Lake City. 
1968

A Comparison of Formative Cultures in the Americas: Diffusion or the Psychic Unity of Man? Smithsonian Contribution to Anthropology, Washington. (in press)

Acknowledgments. I am indebted to the staffs of the American Museum of Natural History and the Florida State Museum for aid in this project. My faculty aides,
Robert Yarrish and Ellen Messer, were of great help, particularly in running down book reviews, as well as giving other crucial aid in checking titles and typing the first draft.

Peabody Museum

Cambridge, Massachusetts June, 1968 